\title{
Title: An Empirical Study on Value Relevance of Fair Value: Based on the Data of Financial Industry and Manufacturing Industry in China
}

Author: Jinyan $\mathrm{Wu}^{1}$

\section{Affiliation:}

1. Accounting and Finance Programme, Durham University Business School, Durham DH1 3LB, UK

Corresponding author: Jinyan Wu. Email: jinyan.wu@dur.ac.uk

\begin{abstract}
Economic development and advancements in information technology contributed to the shift on accounting objective from commission responsibility view to decision-making useful view. The decision-making useful view claims that the accounting measurement methods should be changed to improve the usefulness of accounting information, to enable information users to make correct decisions. In addition, the development of financial instruments leads to the birth of fair value accounting. In recent years, fair value has been one of the most important measurement methods in the International Accounting Standard and US Generally Accepted Accounting Principles. However, China has been quite cautious when it comes to applying fair value full time, especially after the global financial crisis happened in 2008, wherein fair value accounting was exposed to strong suspicion. Hence, studying the value relevance of fair value is of great significance to exploring the accounting profession and reforming accounting standards. This paper attempts to investigate the value-relevance of fair value based on the data of listed financial companies and manufacturing companies in China. The results indicate that the fair value information in the financial industry has a strong explanatory influence to corporate share price. In contrast, the fair value information shows limited relevance in the manufacturing industry. Finally, consulting with the results of normative analysis and empirical study, this paper suggests several rational advices for the application of fair value in China.
\end{abstract}

Keywords: fair value; value-relevance; decision-making useful view; price model 


\section{Introduction}

From the 1980s, economic development and interest rate marketization promoted the creation and innovation of various financial instruments. During the financial crisis, the values of financial instruments disclosed on financial statements significantly deviated from their true values. However, the heavy losses were covered by constant historical cost so that all corporate reports, on the surface, appeared impressive. Some deposit and financial loan institutions used historical cost to hide huge debts. Investors were not able to obtain true and fair accounting information to stop losses. From 1980 to 1994, there approximately 1300 financial institutions went into bankruptcy. From then on, the concept of fair value was put forward by scholars. In 1990, the chairman of U.S. Securities and Exchange Commission Breeden recommended using fair value to measure financial instruments strongly, which improved the development of fair value accounting in the US. Though fair value appeared in SFAS No.12 in 1975 for the first time, its definition was quite inaccurate and the standard failed to provide guidance as it relates to detailed application. After experiencing a four-time revision, an improved standard SFAS No.157 was issued in America in 2006.

Though the application of fair value improves the quality of accounting information to some extent, it is a highly discussed topic and an important issue in the accounting profession at all times, especially when the financial crisis swept the globe in 2008. Many scholars hold the view that fair value is the primary cause of financial crisis. The main criticism about fair value accounting is the pro-cyclical effects. This primarily amplifies gain and loss under different market situations because it is over-sensitive[1]. Under fair value accounting, the value of asset is allowed to be written up and written down; as such, when the market is preposterous, the market value of asset tends to increase. Asset write-ups enable companies to increase leverage, which introduces high risks to corporate finance[2]. However, when it comes to macroeconomic depression, fair value write-downs magnify losses and cause panic among investors. Investors continuously sell off their financial assets, thus, resulting in further deterioration of the macro-economy. Hence, many critics advised SEC to stop using fair value accounting. At the end of 2008, SEC published a survey report, which provided convincing evidences that fair value accounting did not contribute to financial crisis directly. SEC claimed that fair value accounting could improve the quality of accounting information and protect investors' interest.

In China, fair value appeared in an accounting standard for the first time in 1998. Owing to lack of regulation and detailed guidance on application, multiple instances of financial fraud took place following the issue of the standard. Consequently, some fair value standards were deleted in the revised accounting standard of 2001. After joining WTO in 2002, in order to keep consistent with other western countries on the accounting field, fair value accounting was re- 
enabled in China. In 2006, CAS No.39 was enacted to regulate its use. However, the Chinese accounting standard, clearly outlines the fact that the primary measurement method should be historical cost, thus, indicating a cautious attitude toward fair value accounting.

In this paper, we attempt to investigate the value relevance of fair value. This topic is of great importance, as it can provide theoretical support to the accounting standard setting. Under the decision-making useful view, the objective of primary accounting is to offer useful information to help investors making correct investment decisions. Many scholars believe that compared with historical cost, fair value is more timely and relevant as a result of its reliance on market value. Investors could learn about up-to-date information about corporate financial position and operation situations though fair value information, which helps them to make more accurate and relevant decisions; from a theoretical perspective, these advantages do exist. Nevertheless, we need more evidences to prove whether the application of fair value provides more relevant information and improves the quality of accounting information in practice.

Though the value-relevance of fair value has been examined extensively in the US, limited studies have been performed in China. A significant amount of studies conducted in the US and other western countries arrived at a similar conclusion, that fair value is value relevant. However, this result may not be applicable in China. Fair value accounting is a market-based system, which needs the support of an open, active and transparent market environment. China is an emerging market country, which is in its infancy on market economy. Unlike developed countries, China is still yet to house a market environment. Thus, the results of foreign researches have less reference value for China. It is necessary to conduct the study based on our market conditions and the data of Chinese companies.

Most existing studies on value-relevance of fair value in China focus on all listed firms or solely on the financial industry. The financial industry is different from other industries, because it usually holds a great number of financial instruments measured by fair value, so that the effects of fair value would be magnified. In order to improve the accuracy and realistic value of the results, this paper uses grouping test to investigate value-relevance of fair value in the financial industry and manufacturing industry respectively. To conclude, the research aims to provide theoretical support to accounting standards' setting and offer guidance on the further application of fair value accounting in China. 


\section{Literature Review}

\subsection{Fair Value Accounting}

The origin of fair value can be traced back to 1800s. According to Richard[3], French have used some kinds of fair value at that time. In 1929, an economist Canning put forward in his book The Economics of Accountancy that the gain or loss raised by the changes of assets' value should be recognized immediately. It can be seen as the rudiment of fair value. An important event which directly promoted the orientation of fair value accounting is the saving and loans crisis in America during the 1980s. At that time, banks and lending institutions used short-term deposits for long-term fixed rate loans. However, financial institutions had to pay an interest rate to short-term savers, which was even higher than the fixed rate they earned, as inflation pushed the interest rate into a high level. That is to say, the "current value" of assets is lower than the value of liabilities. Consequently, a great number of financial institutions went into bankruptcy. This event reveals that historical cost reduce the transparence and timeliness of accounting information. Bonaci and Tudor[4] concerned it was this crisis that leads people to rethink the deficiencies of the historical cost measurement.

After experiencing about one hundred years development, fair value becomes one of the most important accounting measurement methods. However, scholars still have different opinions on the advantages and limitations of fair value. The debate on fair value is centered around the trade-off between relevance and reliability. Advocates of fair value claim that the information provided by fair value is more relevant and timely. White[5] in his paper The Disintegration of The Depositary Organizations: Bank and Depositary Organizations Public Experience stated that historical cost is inappropriate to financial institutions because it relies on the past. Banks and other financial institutions should be encouraged to use current value accounting. Barth[6] investigated how the disclosed fair value of bank's investment securities and fair value gains and losses are reflected in share prices compared with historical costs and came a conclusion that fair value has more information content. Allen and Carletti[7] compared the assessment ability of fair value and historical cost in financial institution's solvency and suggested that historical cost accounting could only reflect losses gradually by negative earnings. In contrast, fair value accounting is more sensitive and useful to reveal potential risks. Ayres et.al.[8] examined the effect of fair value accounting on the behaviour of analysts and found a positive relationship between fair value asset holdings and forecast accuracy. They challenged the notion that fair value information is less reliable and documented that analyst bias can be reduced by fair value measurements. However, critics of fair value accounting concerned that fair value may be less reliable than historical cost. The result of Lys's[9] study shows that the measurement method used in establishing fair values leads to an understatement of the value of financial assets and an overstatement of financial liabilities. Shleife[10], Barberis and 
Thaler[11] claimed that because of the existence of transaction cost, arbitrage and information asymmetry in the market, fair value could not always reflect the true fundamental value of assets. Therefore, fair value is not accurate enough. Ramanna[12] revealed that under SFAS No.142 (accounting for acquired goodwill) which is a standard relies on fair value estimate, firms have more discretion to manage their financial reports. Similarly, Lin et.al.[13] investigated the relationship between accounting restatements and the use of fair value. They pointed out that firms with more level 3 fair value assets are more likely to restate their financial statements. Their further analysis shows that the restatements are normally caused by managerial manipulation.

Another concern is that fair value accounting could increase volatility to the market and company itself. Plantin et.al.[14] considered that under fair value accounting, asset write-ups allow banks to increase leverage in period of economic expansion, which make the financial system more vulnerable and bring volatility and contagion to financial market. Adrian and Shin[15] used the sampling data of American financial institutions and found that financial institutions using fair value could suffer pro-cyclical effects, which may bring more risks to banking and capital market. Magnan et.al.[16] conducted an empirical study based on the data of US bank holding companies and came a conclusion that fair value accounting induces artificial volatility to financial statements. What's more, the wider the range of a bank's using of fair value reporting, the greater the dispersion in analysts' forecasts.

Though fair value accounting has some undeniable weakness, both Financial Accounting Standards Board and International Accounting Standard Board have required firms to measure financial instruments based on fair value[17]. However, for China which is an emerging market country, there are still some problems in promoting fair value. Peng and Bewley[18] investigated whether fair value accounting is desired and feasible in China. They pointed out that unlike developed countries, China has less developed financial market and less advanced pricing techniques, which makes it harder to obtain a fair value for asset either by current market price or by valuation techniques. Zheng and Andrew (2015) documented that the application of fair accounting in China lacks the support of right infrastructure. Specifically, the absence of regulations and law enforcement makes it difficult for companies to use fair value accounting under a correct and detailed guidance. Also, lacking professional knowledge is another concern in the implement of fair value accounting.

\subsection{Value Relevance of Fair Value}

China introduced fair value into accounting standard in 1998 for the first time, however, there is not specific accounting standard aiming at fair value until the CAS No.39 was enacted in 2006. Because of the short development history of fair value in China, there is a limited number of 
researches on value relevance of fair value. However, many related studies have been conducted in the US and other developed countries.

In 1991, SFAS No.107 was carried out by Financial Accounting Standards Board in America. This standard required all corporations to disclose financial assets and financial liabilities by fair value. In 1994, SFAS No.119 extended the range to derivative financial instruments. Hence, most early studies about value relevance of fair value focused on specific types of financial instruments of banks and other financial institutions and the topic is mainly about whether fair value could provide incremental value relevance compared with historical cost.

Several pieces of research have clearly shown that fair value is value relevant. Barth[6] investigated how share prices reflect bank's investment securities and securities gains and losses measured by fair value. He selected samples from US banks whose financial statement data were on the 1990 Compustat Annual Bank Tape. The results of the empirical study reveal that fair value estimates of investment securities have more significant explanatory power compared with historical cost. Barth also pointed out that though estimation error in the disclosed fair value is small enough which does not affect the value relevance of investment securities' fair value, when two annual fair value estimates are used to calculate gains and losses of securities, the influences of combined estimation errors could result in securities gains and losses value-irrelevant. In 1996, Barth [19]conducted a further study on the data of 136 American listed banks. He found there is a relationship between companies' long-term liabilities and share prices. Therefore, he considered that fair value has significant value-relevance. Venkatachalam[20] extended the range of study to derivative financial instruments. He collected two-years data of 99 banks in the US to investigate whether off-balance-sheet derivative financial instruments measured by fair value are value relevant. The empirical result shows that after controlling the effects of other financial assets and liabilities listed in balance sheet, the fair value of derivative financial instrument still possess value-relevance. Another advocate of fair value accounting is Mengle[21]. He performed a study on the basis of the data of bank industry in America to discusses the practicability of further use of fair value. The result illustrates that fair value is not only value-relevant, but also helpful to reduce the manipulation on financial statements by managers.

Nelson[22] and Eccher et.al.[23] detected the value relevance of fair value disclosure under SFAS No.107 using similar methods. However, the result of their studies is conflicted. Nelson collected the data of the largest 200 banks in America over the period 1992-1993 and investigated the relationship between the market value of shareholders' equities and fair value information required to be disclosed by SFAS No.107. According to his study, the difference between fair value and book value only shows value relevant on investment securities. In terms of loans, bank deposit and long-term liabilities, fair value information is irrelevant. However, 
after eliminating the influences from return on asset and book value growth rate, the explanatory power of price model decreases considerably. At the same time, the fair value of investment securities is no longer value relevant. This conclusion was also confirmed by return model.

Eccher et al. [23] chose 300 American banks which prepared their financial statements according to SFAS No.107 as the samples. They documented that the fair value of investment securities has significance value relevance. For loans, fair value also shows value relevance, but it is weaker than that of investment securities. The finding reveals that though the measurement errors of fair value estimation on non-tradable assets are much larger than that on tradable assets, the problem is not as serious as fair value accounting critics considered. They also detected the substitutability and complementarity between fair value and historical cost. The result of 1992's samples shows mutual incremental value-relevance between the two measurement attributes. Nevertheless, the results of 1993's samples are opposite. Therefore, Eccher et.al. concerned that though fair value could provide incremental information content, historical cost is more applicable on some specific items. That is to say, historical cost can't be substituted perfectly by fair value. In terms of the conflict results compared with Nelson's study[22], they explained it is resulted from different sample sizes, independent variables and control variables.

After re-analyzing the results of Eccher et.al.'s study[23], Lys[9] came to a different conclusion. He pointed out that the results are not able to provide evidence for the value-relevance of fair value under SFAS No.107. The reason is that disclosed fair values of assets and liabilities by firms are biased from how they are estimated by investors. Using current evaluation methods, the fair value of financial assets are understated but are overstated on financial liabilities. Therefore, only when investors correct their estimations on the market value of assets and liabilities according to disclose fair value information by companies, can we confirm that the disclosed fair value information is value relevant.

There are also some other scholars who hold the view that fair value is value irrelevant or has weak value relevance. Petroni and Wahlen[24] analyzed the relationship between the fair value of equity, fixed maturity debt securities and share price of property-liability insurers. They found in contrast to book value which is value relevant for all categories of investments, fair value is only value relevant for certain categories of investment securities, such as equities and US treasury securities, which are more likely to be traded in active markets. They further concerned that the worries about the application of fair value are reasonable, especially when it comes to those assets and liabilities which do not have observable trade prices in an active market. Khurana and Kim[25] put forward similar opinions. After analyzing the data from US bank holding companies over 1995 to 1998, they discovered that there is not obvious 
difference between the value-relevance of fair value and historical cost. What's more, for those banks which are in small scales, historical cost tends to provide more relative information contents. Hence, they suggested that simply requiring fair value as reported measurement method could not improve the quality of information unless appropriate estimation methods are used by firms.

In late 2007, SFAS No.157 was enacted in the US. This standard divides fair value into three hierarchies based on inputs used to generate fair values: (1)Level 1: observable inputs from quoted prices in active markets. (2)Level 2: indirectly observable inputs from quoted prices of comparable items in active markets, identical items in inactive markets, or other market-related information. (3) Level 3: unobservable, firm-generated inputs. From then on, many scholars started to study the value-relevance of each level of fair value hierarchy. Afterwards, many scholars started to investigate the value relevance of different hierarchies.

Kolev[26] used a sample of large firms for the first and second quarters of 2008 to empirically test whether the three fair value hierarchies mandated by SFAS No.157 are value relevant. He documented a positive and significant relationship between market price and Level 1, Level 2 and Level 3 estimates. In addition, Kolev examined the relative investors assessment of the fair value estimates which are reported by firms. The result reveals that there is not obvious differences between Level 1 and Level 2 fair value in their value-relevance. However, Level 3 fair value measurements were found to be placed less weight by investors when they make equity-pricing decisions. Kolev also found that the value relevance of Level 2 and Level 3 fair value are influenced by management's implied incentives and opportunity to bias the reported fair value estimates. What's more, he suggested that when the market isn't liquid enough, information risk is high or corporate governance is inefficient, Level 2 and Level 3, both of which requires estimations would be understated by investors. Goh et al [27] came to a similar conclusion with Kolev. He asserted all the three level of fair value are value relevant. However, if the firm's governance isn't efficient, Level 3 fair value would be value-irrelevant. Level 1 and Level 2 are not influenced by this factor. It is because weak corporate governance increases information asymmetry and reporting bias, and the effects of these factors mainly appear on Level 3 fair value, which relies highly on estimation. Goh et al [27] further extended the research by examining how investors price the different types of fair value estimates after the financial crisis in 2008. He used the combination of time-series and cross-sectional samples from 2008 to 2010 and found that Level 3 fair values are priced lower than Level 1 and level 2 fair values. And in their cross section data, it was revealed that investors discount fair value more for banks with lower capital adequacy. That is to say, investors concerned those banks are more likely to liquidate their assets at much lower prices rather than the fair values reported by banks. 
There are many other scholars who investigated the relationship between fair value and other factors. When examining the effect of realized gains and losses and the effect of changes in unrealized gains and losses on bank stock returns based on the financial statements of 136 banks in America, Ahmed and Takeda[28] discovered that the value relevance of fair value tends to be lower when a firm's profits are manipulated. Hodder et al [29] used the samples of 202 commercial banks over 1996-2004 to compare the volatility of three alternative measures of income. The result shows that using fair value to measure income would generate more significant volatility than using net income and comprehensive income. What's more, the volatility of fair value income has an apparent positive relationship with the standard deviation of bank's stock returns. It means that fair value income could capture the risk factors which cannot be reflected by net income and comprehensive income. Arouri et al[30] collected the data from 80 buy side analysts that specialize in banking and financial institutions to examine how fair value reporting systematically affects industry-specialist analyst's use of risk and performance information in equity security analysis. In contrast to Hodder et al's study, they asserted analysts' investment risk and valuation judgments are not differently influenced by piecemeal reporting formats. That is to say, fair value income can't reflect risk-relevant information.

The studies on value relevance of fair value were also carried out in other developed countries. Bernard et.al.[31] examined the Danish experience with mark-to-market accounting. They came a conclusion that there is not any evidence to proof fair value is manipulated by managers. What's more, fair value serves better in reflecting the changes of firm's value compared with historical costs. However, the volatility of income increases at the same time. Richard et.al.[32] focused on the investment property in the UK and concluded that appraisal fair value understates actual selling prices. Nevertheless, in contrast to historical cost, using fair value measurement is closer to the true value of the investment property. Hung [33] collected the data of German listed companies to investigate how financial statements are affected if International Accounting Standards are adopted. For those items, which were required to be measured by historical costs under German accounting standards, Hung replaced them with fair value measurement according to International Accounting Standards. The result implies that the relevance between relative items and stock price improves considerably.

From above literature review, it can be clearly seen that America is in the leader position in the study on the value-relevance of fair value. There are also some relative researches performed in other developed countries. However, the introduction and application of fair value accounting in China are much later than those developed countries. Hence, China is short of relative studies in this field. Though a majority of existing studies support that fair value is value relevant, for China, which is an emerging market country, the results could be different. So, it's necessary to conduct such a study based on the special market condition in China. Besides, 
most of the existing studies focus on the data of banking and financial institutions only. Under consideration of the difference between financial companies and non-financial companies, which financial companies hold more financial assets measured by fair value, this paper will divide samples into two group: financial and non-financial, and test them respectively to find whether fair value disclosure is value relevant and whether the value relevance of fair value in financial companies is more significant. 


\section{Data and Methodology}

\subsection{Theoretical Basis}

The theoretical basis of the study on the value-relevance of fair value includes the efficient market hypothesis and decision-making useful theory.

The efficient market hypothesis was presented by Fama[34], which is the theoretical basis of value-relevance. According to Fama's conclusion, if all available information on the capital market can be reflected in stock price, the market is efficient. EMH asserts that investors will use all information in capital market which they can access to make decisions on buying or selling stocks. That is to say, the changes of share price are the reflections of all relevant information. According to the sensitivity of share price changes to relevant information, the market can be classified into three types: strong-efficiency market, semi-strong-form efficiency market and weak-form efficiency market. In a strong-efficiency market, share price is able to reflect all information, including public information and private information. For semi-strongform efficiency market, only public information can be reflected. However, in a weak-form efficiency market, future prices cannot be predicted by analyzing past information. Actually, the strong-efficiency market is an ideal status which is very difficult to achieve. Hence, when studying the value-relevance of fair value, we assume that the market is semi strong form.

There are two main opinions of the objective of accounting: commission responsibility view and decision-making useful view. Commission responsibility view emphasizes that the accounting objective of a company is to reflect the capital maintenance and capital appreciation status. Under commission responsibility view, the most important effect of financial reports is to provide true and reliable information. Therefore, historical cost measurement method is advocated because of its faithfulness, objectivity and verifiability. However, in the 1980s, many financial institutions in American started to trade financial instruments. The particularity of financial instruments results in big differences between historical costs and true values with the changes of market environment. Using historical costs to measure financial instruments not only lead investors to make wrong decisions but putting financial institutions into financial distress. Under this circumstance, decision-making useful view came into being.

According to decision-making useful view, corporate accounting objective is to provide useful information to help investors making decisions. In contrast to commission responsibility view, decision-making useful view focuses on what influences the information has on stakeholders. Under the consideration that buying or selling decisions which investors need to make are future-oriented, the high-quality accounting information should be able to reflect the current situations and predict future situations. Fair value accounting meets the requirement by 
consulting with trading prices in a fair and open market as well as valuation techniques to provide fair and timely accounting information. As a result, it is advocated by scholars who support decision-making useful view. They believe that the market-based information is the most relevant financial data for financial reports users.

\subsection{Research Question and Hypothesis}

This study attempts to investigate the value-relevance of fair value. When performing the empirical study on this topic, most previous researches are based on the data of banking or financial institutions only. Under consideration of the difference between financial industry and non-financial industry, which financial companies hold more financial assets measured by fair value and could be greatly influenced by the changes of fair value, this paper will divide samples into two group: financial companies and non-financial companies to test is there any difference on the extent of value-relevance of fair value between the two industries. The study puts forward following research questions:

Are the fair value disclosures value relevant for companies in financial and non-financial industries in China?

Whether the value-relevance of fair value information is more significant for financial companies?

On statistics, if there is any significant correlation between a certain accounting information and share price or stock trading volume, it can be proved that the accounting information is value relevant. Thus, two hypotheses below are developed based on the basic theories and research questions:

1. Gain and loss arising from fair value changes are value relevant.

2. Gain and loss arising from fair value changes for financial companies are more relevant to share price compared with non-financial companies.

Accounting to China Accounting Standard No.39, all financial instruments should be measured at fair value. Among financial assets, there are two main items which have impacts on the net profit and net asset. The first one is financial assets at fair value through profit or loss. Gain and loss arising from fair value changes of this item are disclosed in the income statement and will influence the earning per share eventually. The second is one is available-for-sale financial assets. Fair value changes of available-for-sale financial assets are included in other comprehensive income in the balance sheet and will affect the net asset. As we mentioned above, gain and loss arising from fair value changes are consist of two main parts. Hence, we can divide the first hypothesis into the following sub-hypotheses: 
1a. Gain and loss arising from fair value changes of financial assets at fair value through profit or loss are relevant to share price.

1b. Gain and loss arising from fair value changes of available-for-sale financial assets are relevant to share price.

\subsection{Model Design}

The previous studies on the value-relevance of fair value aimed to meet the requirements of accounting standards making. Beaver[35] pointed out that judging the relevance of a certain accounting information can be achieved by investigating the relationship between the information and security price. Consequently, the famous Dividend Discount Model, which demonstrates the relationship between earnings and share prices was defined.

$$
P_{t}=\sum\left[D_{t} /(1+r)^{t}\right]
$$

Explanation of the variables:

$\mathrm{P}_{\mathrm{t}}$ : share price at $\mathrm{t}$ time

$D_{t}:$ dividends at $t$ time

$r$ : discount rate

In 1995, Feltham and Ohlson derived Residual Income Valuation Model based on Dividend Discount Model[36], which sets up a functional relation between share price, shareholder's equity and expected earnings. It reveals the influences of accounting information on corporate value directly.

$$
P_{t}=B V_{t}+\sum\left[\left(X_{t}-r\right) B V_{t-1} \times(1+r)^{-t}\right]
$$

Explanation of the variables:

$\mathrm{P}_{\mathrm{t}}$ : share price at $\mathrm{t}$ time

$\mathrm{BV}_{\mathrm{t}}$ : book value of net assets at $t$ time

$\mathrm{X}_{\mathrm{t}-1}$ : rate of return on common stockholders' equity at $\mathrm{t}-1$ time

$r$ : rate of return required by investors

Though the Residual Income Valuation Model is a creation in investigating how accounting information affects the market value of a company, the model still has some shortcomings, including over-complicated format and weak-relevant dependent variables. After having a 
deeper research on the Residual Income Valuation Model, Collins et al.[37] developed it into the Price Model.

$$
P t=\alpha_{0}+\alpha_{1} B V_{t}+\alpha_{2} E_{t}+\mu_{t}
$$

Explanation of the variables:

$\mathrm{P}_{\mathrm{t}}$ : share price at $\mathrm{t}$ time

$\mathrm{BV}_{\mathrm{t}}$ : book value of net assets per share at $t$ time

$E_{t}$ : earnings per share at $t$ time

The Price Model is advocated and used by many scholars in their studies since it was developed because of its simple format and wide applicability. In this model, share price can be represented by net assets per share and earnings per share, which is the information from the balance sheet and income statement respectively. Therefore, it can clearly reflect the associations between the market value of a firm and the accounting information which is disclosed in a corporate financial report.

In this paper, we will use Price Model to conduct an empirical study on the value-relevance of fair value. According to our hypotheses, we change the basic model as follow:

Model 1: $P_{i t}=\beta_{0}+\beta_{1} \times B V_{i t}+\beta_{2} \times F A V I_{i t}+\beta 3 \times E P S L_{i t}+\beta_{4} \times \ln A+\beta_{5} \times D B E T+\varepsilon_{i t}$

Model 2: $P_{i t}=\beta_{0}+\beta_{1} \times F V A D_{i t}+\beta_{2} \times B V B F V_{i t}+\beta 3 \times E P S_{i t}+\beta_{4} \times \ln A+\beta_{5} \times D B E T+\varepsilon_{i t}$

Variable definitions:

\begin{tabular}{|c|c|}
\hline \multicolumn{2}{|c|}{ Dependent Variable } \\
\hline $\mathrm{P}_{\text {it }}$ & closing share price of April 30th \\
\hline \multicolumn{2}{|c|}{ Independent Variables } \\
\hline $\mathrm{BV}_{\text {it }}$ & book value of net assets per share \\
\hline EPS $_{\text {it }}$ & earnings per share \\
\hline FAVI $_{\text {it }}$ & gain and loss arising from fair value changes per share \\
\hline EPSL $_{\text {it }}$ & EPS minus FAVI ${ }_{\text {it }}$ \\
\hline FVAD $_{\text {it }}$ & fair value changes of available-for-sale financial assets per share \\
\hline BVBFV $_{\text {it }}$ & $\mathrm{BV}_{\text {it }}$ minus FVAD it \\
\hline \multicolumn{2}{|c|}{ Control Variables } \\
\hline $\ln \mathrm{A}$ & natural logarithm of corporate total assets \\
\hline DBET & asset-liability ratio \\
\hline
\end{tabular}

Note: $\mathrm{I}=$ firm,t=time. 
As mentioned above, gain and loss arising from fair value changes are consist of two main parts. Hence, we use Model 1 and Model 2 to test the value-relevance of the fair value of the two financial assets respectively. In the first model, we divided the EPS in the Price Model into FAVlit and EPSL ${ }_{i t}$. If coefficient $\beta_{2}$ in the Model 1 is significantly different from zero, hypothesis 1 a can be accepted. That is to say, gain and loss arising from fair value changes of financial assets at fair value through profit or loss are relevant to share price. Similarly, we replace net assets per share with $F V A D_{i t}$ and $B V B F V_{i t}$. A significant value for coefficient $\beta_{1}$ in the Model 2 will imply that gain and loss arising from fair value changes of available-for-sale financial assets are relevant to share price. The value-relevance of fair value can be confirmed when both $\beta_{2}$ (in Model 1 ) and $\beta_{1}$ (in Model 2) are significant. Moreover, if the estimated coefficients $\beta_{2}$ and $\beta_{1}$ for financial companies are obviously bigger than those of non-financial companies, hypothesis 2 can be accepted.

In our model, we use total assets and asset-liability ratio as control variables. According to Supply and Demand Principles in economics, the quantity demanded of a product is SR at a certain price. When quantity supplied increases, product price will decline. Similarly, a larger company could have more tradable stocks in the stock market. Ceteris paribus, its share price could be lower. Thus, the size of a company has a negative influence on stock price. In this paper, we use natural logarithm of total assets to represent company's scale.

The asset-liability ratio is able to reflect the capital structure of a company. Normally, a higher asset-liability ratio leads to higher financial risks. Consequently, a company with high assetliability ratio should have a high market value based on risk and return matching principle. On the other hand, firms with a great number of debts need to divide more earnings to creditors as the investment return. Correspondingly, their share price would decrease because of less remained earnings for shareholders. To conclude, how asset-liability ratio affects stock price depends on which factor accounts for the main part in comprehensive effects.

According to the requirement made by China Securities Regulatory Commission, a company must publish this year's financial statements before May of next year. In order to increase horizontal comparability, we use the closing stock price in April $30^{\text {th }}$ of each year to measure companies' share prices.

\subsection{Samples}

The initial sample of this study is comprised of all companies in financial industry and manufacturing industry, which are listed in China A share market. The resource of the data is WIND Economic Database, and the benchmark used in the study to classify industries is the one which was issued by China Securities Regulatory Commission in 2012. 
There are 74 listed firms in financial industry and 2106 listed firms in manufacturing industry during the sample period 2012 to 2016. After eliminating ST companies (earnings suffering two consecutive years of losses) and *ST companies (earnings suffering two consecutive years of losses and would be delisted in the next year) as well as the companies whose fair value changes equal to zero, 44 financial firms and 325 manufacturing firms remained. Eventually, we get 220 effective samples and 1625 effective samples in financial industry and manufacturing industry respectively. 


\section{Results}

\subsection{Empirical Study on Financial Companies}

\section{(1) Descriptive Statistics}

Descriptive statistics analysis on Model 1 and Model 2 has been performed and the results are outlined as follows:

Table 4.1 Descriptive Statistics of Variables in Model 1(Financial Companies)

\begin{tabular}{cccccc}
\hline Variables & $\mathrm{N}$ & Minimum & Maximum & Mean & $\begin{array}{c}\text { Standard } \\
\text { Deviation }\end{array}$ \\
\hline P & 220 & 2.4200 & 88.6600 & 14.3879 & 11.0001 \\
BV & 220 & 1.2911 & 32.5600 & 7.2874 & 4.5485 \\
FAVI & 220 & -0.3256 & 0.7584 & 0.0100 & 0.0941 \\
EPSL & 220 & -0.5785 & 4.8608 & 0.9212 & 0.8034 \\
LNA & 220 & 20.6408 & 30.8148 & 26.4537 & 2.5420 \\
DEBT & 220 & 1.9555 & 94.9843 & 76.4998 & 21.5490 \\
\hline
\end{tabular}

Table 4.2 Descriptive Statistics of Variables in Model 2(Financial Companies)

\begin{tabular}{cccccc}
\hline Variables & $\mathrm{N}$ & Minimum & Maximum & Mean & $\begin{array}{c}\text { Standard } \\
\text { Deviation }\end{array}$ \\
\hline $\mathrm{P}$ & 220 & 2.4200 & 88.6600 & 14.3879 & 11.0001 \\
FVAD & 220 & -82.4920 & 174.2158 & 2.0709 & 14.2061 \\
BVBFV & 220 & -158.6550 & 92.8429 & 5.2165 & 14.1277 \\
EPS & 220 & 0.0084 & 4.9300 & 0.9312 & 0.8057 \\
LNA & 220 & 20.6408 & 30.8148 & 26.4537 & 2.5420 \\
DEBT & 220 & 1.9555 & 94.9843 & 76.4998 & 21.5490 \\
\hline
\end{tabular}

The minimum and maximum of FAVI is -0.3256 and 0.7584 respectively with the standard deviation of 0.0941. On average, gain and loss arising from fair value changes is 0.0100 , which is nearly equal to 0 . This reflects the notion that all financial companies adopted a cautious attitude to fair value accounting. They did not use fair value widely in practice and fair value changes did not have a significant influence on their earnings. 
Though the mean of FVAD is 2.0709 , the difference between the biggest and smallest value reaches 256.7078. The big standard deviation of 14.2061 also implies the significant difference. After further analysing the data, we found that the majority of financial companies have small FVAD, with the extreme values resulting from certain companies. For example, the FVAD of Xishui Strong Year Company in 2015 and 2016 reflect the maximum and minimum value in the financial industry. According to Xishui's annual financial reports, the gain and loss arising from fair value changes were mainly as a result of the large number of bonds, financial products and trust investments they hold. Xinhua insurance company and Bank of Shanghai also have a bigger FVAD than the industry average, because they possessed massive available-for-sale financial assets. To conclude, fair value accounting is used with caution in the financial industry, and fair value changes do not substantially affect corporate earnings and net assets. This phenomenon is related to the accounting standards in our country, which clarify that historical cost should be the priority option for corporations.

The share price varies in a wide range from 2.42 to 88.66 , with a big standard deviation of 11.0001. The significant difference is derived from the different operating situations of financial companies. It is also affected by the instability of China's stock market. Another significant difference can be found in DEBT. The lowest asset-liability ratio is $1.96 \%$ among the 44 financial firms. However, the highest one reaches $94.98 \%$. This suggests diverse capital structures of different companies. Some financial institutions prefer high-risk capital structure by extensive financing. On the contrary, others choose a conservative capital structure to maintain steady progression.

\section{(2) Correlation Analysis}

Before conducting the regression analysis, we attempt to investigate if any linear relationship exists among variables in Model 1 and Model 2 by testing Pearson correlation coefficient. 
Table 4.3 Correlation Analysis of Variables in Model 1(Financial Companies)

\begin{tabular}{|c|c|c|c|c|c|c|c|}
\hline & & $\mathrm{P}$ & BV & FAVI & EPSL & LNA & DEBT \\
\hline $\mathrm{P}$ & $\begin{array}{l}\text { Pearson Correlation } \\
\text { Coefficient } \\
\text { Statistical Significance } \\
\text { (two-sided) }\end{array}$ & 1 & & & & & \\
\hline BV & $\begin{array}{l}\text { Pearson Correlation } \\
\text { Coefficient } \\
\text { Statistical Significance } \\
\text { (two-sided) }\end{array}$ & $\begin{array}{c}.589^{* *} \\
.000\end{array}$ & 1 & & & & \\
\hline FAVI & $\begin{array}{c}\text { Pearson Correlation } \\
\text { Coefficient } \\
\text { Statistical Significance } \\
\text { (two-sided) }\end{array}$ & $\begin{array}{l}.166^{*} \\
.014\end{array}$ & $\begin{array}{l}.044 \\
.513\end{array}$ & 1 & & & \\
\hline EPSL & $\begin{array}{l}\text { Pearson Correlation } \\
\text { Coefficient } \\
\text { Statistical Significance } \\
\text { (two-sided) }\end{array}$ & $\begin{array}{c}.400^{* *} \\
.000\end{array}$ & $\begin{array}{l}.860^{* *} \\
.000\end{array}$ & $\begin{array}{l}-.034 \\
.613\end{array}$ & 1 & & \\
\hline LNA & $\begin{array}{l}\text { Pearson Correlation } \\
\text { Coefficient } \\
\text { Statistical Significance } \\
\text { (two-sided) }\end{array}$ & -.066 & $.425^{* *}$ & -.007 & $\begin{array}{l}.564^{* *} \\
.000\end{array}$ & 1 & \\
\hline DEBT & $\begin{array}{c}\text { Pearson Correlation } \\
\text { Coefficient } \\
\text { Statistical Significance } \\
\text { (two-sided) }\end{array}$ & .097 & $.429^{* *}$ & .032 & $.546^{\star \star}$ & $.838^{\star *}$ & 1 \\
\hline
\end{tabular}

Notes: ** and * indicate the coefficient is statistically significant at $1 \%$ and $5 \%$ significance level respectively.

It can be clearly seen that the coefficients of BV, FAVI and EPSL are all significant on a 1\% significance level, which indicate that positive relationships exist between these variables and the dependent variable P. This provides evidence for Ohlson's model: corporate net assets, earnings and share prices are correlated. Compared with BV and EPSL, the coefficient of FAVI is smaller. It demonstrates that gain and loss arising from fair value changes do not have significant effects on neither corporate earnings nor its share price. 
Table 4.4 Correlation Analysis of Variables in Model 2(Financial Companies)

\begin{tabular}{|c|c|c|c|c|c|c|c|}
\hline & & $\mathrm{P}$ & FVAD & BVBFV & EPS & LNA & DEBT \\
\hline $\mathrm{P}$ & $\begin{array}{c}\text { Pearson Correlation } \\
\text { Coefficient } \\
\text { Statistical Significance } \\
\text { (two-sided) }\end{array}$ & 1 & & & & & \\
\hline FVAD & $\begin{array}{l}\text { Pearson Correlation } \\
\text { Coefficient } \\
\text { Statistical Significance } \\
\text { (two-sided) }\end{array}$ & $\begin{array}{l}.153^{*} \\
.023\end{array}$ & 1 & & & & \\
\hline BVBFV & $\begin{array}{l}\text { Pearson Correlation } \\
\text { Coefficient } \\
\text { Statistical Significance } \\
\text { (two-sided) }\end{array}$ & $\begin{array}{l}.036 \\
.597\end{array}$ & $\begin{array}{r}-.948^{* *} \\
.000\end{array}$ & 1 & & & \\
\hline EPS & $\begin{array}{l}\text { Pearson Correlation } \\
\text { Coefficient } \\
\text { Statistical Significance } \\
\text { (two-sided) }\end{array}$ & $\begin{array}{l}.419^{* *} \\
.000\end{array}$ & $\begin{array}{l}.058 \\
.391\end{array}$ & $\begin{array}{l}.219^{* *} \\
.001\end{array}$ & 1 & & \\
\hline LNA & $\begin{array}{l}\text { Pearson Correlation } \\
\text { Coefficient } \\
\text { Statistical Significance } \\
\text { (two-sided) }\end{array}$ & $\begin{array}{r}-.066 \\
.328\end{array}$ & .000 & $.137^{*}$ & $\begin{array}{l}.562^{* *} \\
.000\end{array}$ & 1 & \\
\hline DEBT & $\begin{array}{c}\text { Pearson Correlation } \\
\text { Coefficient } \\
\text { Statistical Significance } \\
\text { (two-sided) }\end{array}$ & .097 & .064 & .073 & $.548^{* *}$ & $.838^{* *}$ & 1 \\
\hline
\end{tabular}

Notes: $* *$ and $*$ indicate the coefficient is statistically significant at $1 \%$ and $5 \%$ significance level respectively.

Table 4.4 shows the relativities among variables in Model 2. It can be found that the coefficient of FVAD is significant at a $5 \%$ significance level, while EPS is significant at a $1 \%$ level. If we relax the significance at a $10 \%$ level, the coefficient of BVBFV will also be significant. As a result, we can conclude that FVAD, BVBFV and EPS are all positively related to share price. Furthermore, EPS is the most related one, followed by FVAD and BVBFV.

In both models, the coefficients of total assets and asset-liability ration are not significant; therefore, no linear correlation has been found between the two control variables and share price.

\section{(3) Regression Analysis}

a. Regression Analysis on Model 1 
We use statistical analysis software to regress Model 1 based on the data of financial companies and obtain the following results.

Table 4.5 Regression Outcome of Hypothesis 1a(Financial Companies)

\begin{tabular}{cccccc}
\hline Variables & $\begin{array}{c}\text { Unstandardized } \\
\text { Coefficient }\end{array}$ & Std. Error & t-Statistics & Prob. & VIF \\
\hline$\left(\beta_{0}\right)$ & 59.033 & 7.844 & 7.525 & .000 & \\
BV & $\mathbf{1 . 9 7 9}$ & .229 & $\mathbf{8 . 6 3 7}$ & $\mathbf{. 0 0 0}$ & 4.005 \\
FAVI & $\mathbf{1 2 . 8 9 0}$ & $\mathbf{5 . 6 1 3}$ & $\mathbf{2 . 2 9 7}$ & $\mathbf{. 0 2 3}$ & 1.030 \\
EPSL & -1.812 & 1.426 & -1.271 & .205 & 4.839 \\
LNA & $\mathbf{- 2 . 6 6 2}$ & $\mathbf{. 3 8 9}$ & $\mathbf{- 6 . 8 4 8}$ & $\mathbf{. 0 0 0}$ & 3.600 \\
DEBT & $\mathbf{. 1 6 8}$ & $\mathbf{. 0 4 5}$ & $\mathbf{3 . 7 4 2}$ & $\mathbf{. 0 0 0}$ & 3.469 \\
\hline Adjusted R & $\mathbf{0 . 5 0 9}$ & & & & \\
F-Statistics & $\mathbf{4 6 . 4 5 8}$ & & & & \\
Prob.(F-Statistics) & $\mathbf{0 . 0 0 0}$ & & & & \\
\hline
\end{tabular}

The adjusted $R^{2}$ is 0.509 , which implies that $50.9 \%$ of the dependent variable can be explained by independent variables in Model 1 . The model has a relatively high fitting precision. The value of F-statistics is $\mathbf{4 6 . 4 5 8}$ and the probability is 0 . These illustrate that the linear regression between share price and the independent variables are highly significant. The values of VIF smaller than 5 demonstrate there is no multicollinearity among variables. Hence, the regression results are valid.

The coefficient of FAVI is 12.890 , and it is significant at a $5 \%$ significance level. Thus, FAVI has significant positive influences on stock price. That is to say, fair value changes of financial assets at fair value through profit or loss are value relevant. Hypothesis 1a can be accepted. On the contrary, no relation is found between EPSL and share price. This may be due to the particularity of the financial industry, where financial assets take a majority of their total assets. As a result, investors care more about the gain and loss from financial instruments other than the total earnings.

The coefficients of BV, LNA and DEBT are also significant. BV and DEBT are positively related to share price, wherein LNA has negative effects. However, their coefficients are smaller than that of FAVI, which suggests that FAVI is one of the most important influencing factors of stock price. Compared with net assets, total assets and asset-liability ratio provided in the balance sheet, investors focus more on the information about earnings. This is so, it can reflect the 
profitability of a company, and has influences on stocks' appreciation space and how much dividends can be received by shareholders.

b. Regression Analysis on Model 2

Table 4.6 Regression Outcome of Hypothesis 1b(Financial Companies)

\begin{tabular}{lccccc}
\hline Variables & $\begin{array}{c}\text { Unstandardized } \\
\text { Coefficient }\end{array}$ & Std. Error & t-Statistics & Prob. & VIF \\
\hline$\left(\beta_{0}\right)$ & 61.055 & 7.944 & 7.685 & .000 & \\
FVAD & $\mathbf{1 . 9 4 2}$ & $\mathbf{. 2 3 3}$ & $\mathbf{8 . 3 2 8}$ & $\mathbf{. 0 0 0}$ & 39.220 \\
BVBFV & $\mathbf{1 . 9 4 7}$ & $\mathbf{. 2 4 0}$ & $\mathbf{8 . 1 1 7}$ & $\mathbf{. 0 0 0}$ & 41.024 \\
EPS & -1.445 & 1.465 & -.987 & .325 & 4.975 \\
LNA & $\mathbf{- 2 . 7 5 6}$ & $\mathbf{. 3 9 5}$ & $\mathbf{- 6 . 9 8 2}$ & $\mathbf{. 0 0 0}$ & 3.598 \\
DEBT & $\mathbf{. 1 7 5}$ & $\mathbf{. 0 4 6}$ & $\mathbf{3 . 8 1 9}$ & $\mathbf{. 0 0 0}$ & 3.501 \\
\hline
\end{tabular}

The regression outcome of Model 2 shows that the VIF of FVAD and BVBFV exceed 10. That is to say, multicollinearity may affect the accuracy of regression results. Therefore, we utilize the stepwise regression method to eliminate multicollinearity and obtain the following results:

Table 4.7 Adjusted Regression Outcome of Hypothesis 1b(Financial Companies)

\begin{tabular}{lccccc}
\hline Variables & $\begin{array}{c}\text { Unstandardized } \\
\text { Coefficient }\end{array}$ & Std. Error & t-Statistics & Prob. & VIF \\
\hline$\left(\beta_{0}\right)$ & 72.672 & 8.916 & 8.151 & .000 & \\
FAVD & .074 & .043 & 1.727 & .086 & 1.017 \\
EPS & $\mathbf{8 . 4 7 7}$ & $\mathbf{. 9 2 1}$ & $\mathbf{9 . 2 0 8}$ & $\mathbf{. 0 0 0}$ & 1.510 \\
LNA & $\mathbf{- 2 . 9 9 6}$ & $\mathbf{. 4 4 9}$ & $\mathbf{- 6 . 6 6 9}$ & $\mathbf{. 0 0 0}$ & 3.578 \\
DEBT & $\mathbf{. 1 6 9}$ & $\mathbf{. 0 5 2}$ & $\mathbf{3 . 2 2 1}$ & $\mathbf{. 0 0 1}$ & 3.500 \\
\hline Adjusted R & $\mathbf{0 . 3 4 1}$ & & & & \\
F-Statistics & $\mathbf{2 9 . 2 7 0}$ & & & & \\
Prob.(F-Statistics) & $\mathbf{0 . 0 0 0}$ & & & & \\
\hline
\end{tabular}

The adjusted $R^{2}$ of 0.341 means a $34.1 \%$ dependent variable can be explained by independent variables in Model 2, thus, independent variables have less explanation power as it relates to share price. 
The coefficients of EPS and DEBT, as well as LNA are significant at a $5 \%$ level. However, EPS and DEBT are positively correlated to share price, among which EPS has more important influences. Therefore, the earning situation is emphasized by the investors when they measure the value of a corporation. The coefficient of LNA is negative, which implies that a bigger size company could have a lower share price. The phenomenon can be explained by Supply and Demand Principles in economics.

FAVD is not significant at a $5 \%$ significance level. However, if we relax the level to $10 \%$, it will be significant. Hence, gain and loss casing by fair value changes of available-for-sale financial assets are value relevant to share price; thus, hypothesis $1 \mathrm{~b}$ can be accepted. Nevertheless, the coefficient of FVAD is smaller than that of FAVI, which suggests that the effects of FVAD are weak compared with FAVI. In other words, financial assets at fair value through profit or loss are more relevant to share price in financial corporations.

\subsection{Empirical Study on Manufacturing Companies}

\section{(1) Descriptive Statistics}

The results of descriptive statistics of the two models in manufacturing companies are shown below:

Table 4.8 Descriptive Statistics of Variables in Model 1(Manufacturing Companies)

\begin{tabular}{cccccc}
\hline Variables & $\mathrm{N}$ & Minimum & Maximum & Mean & $\begin{array}{c}\text { Standard } \\
\text { Deviation }\end{array}$ \\
\hline P & 1625 & 1.5200 & 158.3700 & 15.0963 & 11.9751 \\
BV & 1625 & 0.0462 & 20.8389 & 4.4858 & 2.6784 \\
FAVI & 1625 & -0.4593 & 0.4847 & 0.0038 & 0.0411 \\
EPSL & 1625 & -3.7838 & 5.1693 & 0.3377 & 0.5450 \\
LNA & 1625 & 19.5056 & 27.3765 & 22.4782 & 1.3038 \\
DEBT & 1625 & 0.7969 & 97.8663 & 45.5323 & 19.7180 \\
\hline
\end{tabular}


Table 4.9 Descriptive Statistics of Variables in Model 2(Manufacturing Companies)

\begin{tabular}{cccccc}
\hline Variables & $\mathrm{N}$ & Minimum & Maximum & Mean & $\begin{array}{c}\text { Standard } \\
\text { Deviation }\end{array}$ \\
\hline P & 1625 & 1.5200 & 158.3700 & 15.0963 & 11.9751 \\
FVAD & 1625 & -1.4621 & 94.8512 & 0.0956 & 2.3671 \\
BVBFV & 1625 & -87.5610 & 20.7281 & 4.3902 & 3.5056 \\
EPS & 1625 & -3.8100 & 4.7100 & 0.3415 & 0.5426 \\
LNA & 1625 & 19.5056 & 27.3765 & 22.4782 & 1.3038 \\
DEBT & 1625 & 0.7969 & 97.8663 & 45.5323 & 19.7180 \\
\hline
\end{tabular}

The minimum and maximum of FAVI are -0.4593 and 0.4847 respectively with the standard deviation of 0.0411 and mean of 0.0038 . The small numbers suggest that fair value was not used widely in practice and has limited effects on corporate earnings. In comparison to the data of financial companies, manufacturing companies are smaller on each item. It is likely caused by the less financial asset holdings in manufacturing companies.

Though the maximal FVAD reaches 94.85 , the mean of FVAD is close to 0 , and the standard deviation is also kept at a low level. These data demonstrated that fair value is rarely used in manufacturing companies and has almost no influence on a corporate financial situation. The FAVD of manufacturing firms is much smaller compared with firms in the financial industry, because of less financial asset holdings of manufacturing companies.

\section{(2) Correlation Analysis}

The results of Pearson correlation analysis for manufacturing companies' data are shown below. 
Table 4.10 Correlation Analysis of Variables in Model 1(Manufacturing Companies)

\begin{tabular}{|c|c|c|c|c|c|}
\hline & & $\mathrm{P}$ & BV & FAVI & EPSL \\
\hline$P$ & $\begin{array}{l}\text { Pearson Correlation } \\
\text { Coefficient } \\
\text { Statistical Significance } \\
\text { (two-sided) }\end{array}$ & 1 & & & \\
\hline BV & $\begin{array}{l}\text { Pearson Correlation } \\
\text { Coefficient } \\
\text { Statistical Significance } \\
\text { (two-sided) }\end{array}$ & $\begin{array}{l}.475^{* *} \\
.000\end{array}$ & 1 & & \\
\hline FAVI & $\begin{array}{l}\text { Pearson Correlation } \\
\text { Coefficient } \\
\text { Statistical Significance } \\
\text { (two-sided) }\end{array}$ & -.040 & -.028 & 1 & \\
\hline EPSL & $\begin{array}{l}\text { Pearson Correlation } \\
\text { Coefficient } \\
\text { Statistical Significance } \\
\text { (two-sided) }\end{array}$ & $.504^{* *}$ & $.638^{* *}$ & $-.095^{* *}$ & 1 \\
\hline
\end{tabular}

Notes: ** and * indicate the coefficient is statistically significant at $1 \%$ and $5 \%$ significance level respectively.

Table 4.10 reveals that the coefficients of BV and EPSL are significant at a $1 \%$ level, which indicates there are positive relationships between the two independent variables and share price $P$. However, the coefficient of FAVI is not significantly different from 0 . Thus, it can be predicted that the gain and loss resulted from fair value changes are not relevant to share price. The reason could be less financial assets at fair value through profit or loss held by manufacturing companies. 
Table 4.11 Correlation Analysis of Variables in Model 2(Manufacturing Companies)

\begin{tabular}{|c|c|c|c|c|c|}
\hline & & $\mathrm{P}$ & FVAD & BVBFV & EPS \\
\hline $\mathrm{P}$ & $\begin{array}{c}\text { Pearson Correlation } \\
\text { Coefficient } \\
\text { Statistical Significance } \\
\text { (two-sided) }\end{array}$ & 1 & & & \\
\hline FVAD & $\begin{array}{c}\text { Pearson Correlation } \\
\text { Coefficient } \\
\text { Statistical Significance } \\
\text { (two-sided) }\end{array}$ & $\begin{array}{l}.016 \\
.513\end{array}$ & 1 & & \\
\hline BVBFV & $\begin{array}{c}\text { Pearson Correlation } \\
\text { Coefficient } \\
\text { Statistical Significance } \\
\text { (two-sided) }\end{array}$ & $\begin{array}{l}.352^{* *} \\
.000\end{array}$ & $\begin{array}{c}-.646^{* *} \\
.000\end{array}$ & 1 & \\
\hline EPS & $\begin{array}{c}\text { Pearson Correlation } \\
\text { Coefficient } \\
\text { Statistical Significance } \\
\text { (two-sided) }\end{array}$ & $.503^{\star *}$ & .027 & $.470^{* *}$ & 1 \\
\hline
\end{tabular}

Notes: $* *$ indicates the coefficient is statistically significant at $1 \%$ significance level.

According to Table 4.11, both BVBFV and EPS are significant at $1 \%$, which reveals an obvious linear relationship between share price and the two variables. That means the increase of earnings and net assets (excluding fair value changes of available-for-sale financial assets) could lead to a rise in stock price. However, the coefficient of FVAD is not significant. It is probable because available-for-sale financial assets held by manufacturing firms are very limited, to avoid revealing the apparent linear relation

(3) Regression Analysis

a. Regression Analysis on Model 1

We conduct a regression analysis to investigate the linear relationship between variables in Model 1. The results are shown below. 
Table 4.12 Regression Parameter Estimation of Variables in Model 1(Manufacturing Companies)

\begin{tabular}{lccccc}
\hline Variables & $\begin{array}{c}\text { Unstandardized } \\
\text { Coefficient }\end{array}$ & Std. Error & t-Statistics & Prob. & VIF \\
\hline$\left(\beta_{0}\right)$ & 72.895 & 4.877 & 14.948 & .000 & \\
BV & $\mathbf{1 . 7 3 5}$ & $\mathbf{. 1 2 4}$ & $\mathbf{1 3 . 9 8 5}$ & $\mathbf{. 0 0 0}$ & 1.966 \\
FAVI & 1.008 & 5.802 & .174 & .862 & 1.013 \\
EPSL & $\mathbf{7 . 8 2 4}$ & $\mathbf{. 5 7 1}$ & $\mathbf{1 3 . 7 1 3}$ & $\mathbf{. 0 0 0}$ & 1.723 \\
LNA & $\mathbf{- 3 . 2 0 2}$ & $\mathbf{. 2 4 3}$ & $\mathbf{- 1 3 . 1 9 5}$ & $\mathbf{. 0 0 0}$ & 1.783 \\
DEBT & $\mathbf{. 0 8 2}$ & $\mathbf{. 0 1 5}$ & $\mathbf{5 . 3 7 8}$ & $\mathbf{. 0 0 0}$ & 1.627 \\
\hline Adjusted R & $\mathbf{0 . 4 0 4}$ & & & & \\
F-Statistics & $\mathbf{1 8 7 . 2 2 3}$ & & & & \\
Prob.(F-Statistics) & $\mathbf{0 . 0 0 0}$ & & & & \\
\hline
\end{tabular}

The adjusted $R^{2}$ of 0.404 illustrates that $40.4 \%$ of the dependent variable can be explained by independent variables in Model 1 , which is an ideal fitting precision. The value of F-statistics is 187.223 and the probability is 0 . These data suggest that there is a significant linear regression correlation between share price and the independent variables. The values of VIF are all smaller than 2; therefore no multicollinearity exists among variables. The regression results are meaningful.

All the coefficients of independent variables are significant at a $5 \%$ significance level, except FAVI. This is most likely due to the few financial assets owned by the manufacturing companies, to avoid fair value changes of financial assets having an apparent effect on their earnings. The result coincides with the correlation analysis.

On the contrary, after excluding FAVI, the remaining earnings per share (EPSL) is positively related to share price. The coefficient of EPSL 7.824 implies that the influences of EPSL are highly significant to share price. Therefore, investors care more about the general earning situation of a manufacturing company, other than the gain and loss arising from fair value changes. We can come to a conclusion that FAVI is not value-relevant to share price. Thus, hypothesis $1 \mathrm{~b}$ is rejected.

Besides, book value of net asset (BV) and asset-liability ratio (DEBT) are both positively correlated to share price, but they do not have such significant influences compared with EPSL. The coefficient of LNA is also significantly different from 0 ; however, it negatively impacts the stock price. It means, for manufacturing firms, an increase in total asset could lead to a decline on share price. 
b. Regression Analysis on Model 2

Table 4.13 Regression Parameter Estimation of Variables in Model 2(Manufacturing Companies)

\begin{tabular}{lccccc}
\hline Variables & $\begin{array}{c}\text { Unstandardized } \\
\text { Coefficient }\end{array}$ & Std. Error & t-Statistics & Prob. & VIF \\
\hline$\left(\beta_{0}\right)$ & 73.264 & 4.892 & 14.975 & .000 & \\
FVAD & $\mathbf{1 . 8 3 4}$ & $\mathbf{. 1 5 9}$ & $\mathbf{1 1 . 5 0 1}$ & $\mathbf{. 0 0 0}$ & 2.539 \\
BVBFV & $\mathbf{1 . 7 3 7}$ & $\mathbf{. 1 2 4}$ & $\mathbf{1 4 . 0 0 1}$ & $\mathbf{. 0 0 0}$ & 3.368 \\
EPS & $\mathbf{7 . 8 2 1}$ & $\mathbf{. 5 7 1}$ & $\mathbf{1 3 . 7 0 5}$ & $\mathbf{. 0 0 0}$ & 1.708 \\
LNA & $\mathbf{- 3 . 2 1 9}$ & $\mathbf{. 2 4 3}$ & $\mathbf{- 1 3 . 2 2 9}$ & $\mathbf{. 0 0 0}$ & 1.793 \\
DEBT & $\mathbf{. 0 8 2}$ & $\mathbf{. 0 1 5}$ & $\mathbf{5 . 3 3 4}$ & $\mathbf{. 0 0 0}$ & 1.625 \\
\hline Adjusted R & $\mathbf{0 . 3 6 4}$ & & & & \\
F-Statistics & $\mathbf{1 8 7 . 0 8 0}$ & & & & \\
Prob.(F-Statistics) & $\mathbf{0 . 0 0 0}$ & & & & \\
\hline
\end{tabular}

In terms of the regression of Model 2 based on data of manufacturing companies, the adjusted $\mathrm{R}^{2}$ is 0.364 , which means $36.4 \%$ dependent variables can be explained by independent variables in this model. The fitting precision is not high enough. One possible reason is we can only select variables according to public information on corporate financial reports. There may be other accounts that include fair value changes, but are not disclosed on financial statements. The value of $F$-statistic is 187.080 and the $P$ value is 0 . It can be reflected that there is a significant linear relationship between dependent variables and independent variables. All of the variables have a small VIF. Consequently, the regression results will not be influenced by multicollinearity.

The coefficient of FVAD is significant at a $5 \%$ significance level. This verifies gain and loss arising from fair value changes of available-for-sale financial assets being positively related to share price. Nevertheless, the small value of 1.834 demonstrates that the effects of FVAD are very limited. It is probably because the available-for-sale assets held by manufacturing companies only take a minority part of their total assets, so the fair value changes cannot affect corporate net assets, as well as share price considerably. Thus, we can conclude that fair value changes of available-for-sale financial assets are value relevant to share price for manufacturing companies. Thus, hypothesis $1 \mathrm{~b}$ can be accepted.

It can be clearly seen from the table that the coefficient of EPS is significantly different from 0 . Moreover, the coefficient of EPS is bigger than all other independent variables. This indicates that EPS is the most important influencing factor of share price. Investors care more about the 
earning situation than other factors when they make investment decisions on manufacturing firms. This empirical result is consistent with the Price Model.

Asset-liability ratio positively affects corporate share price, though it is a less important factor. As a result, capital structure of manufacturing companies is not an essential consideration for investors. On the contrary, the coefficient of LVA is negative, suggesting bigger manufacturing corporations could have lower share prices; it is likely because of Supply and Demand Principles. Specifically, big size companies have more tradable stocks than small size companies; therefore, the share price of big firms would descend due to a large quantity supply.

\subsection{Comparison Analysis}

As we have proved in the empirical results, for financial companies, both FVAI and FVAD are positively related to share price. However, the coefficient of FVAI is much bigger (12.890) and significant at a $5 \%$ significance level, compared with the small coefficient of FVAD (0.074), which is significant at a $10 \%$ level. As such, financial assets, at fair value through profit or loss and available-for-sale financial assets have value-relevance, among which the precious one is more relevant to share price.

We attempt to find possible reasons for the result. Normally, the reason why a company would hold financial asset at fair value through profit or loss is to sell it in the short-term and to earn the spread. In contrast to available-for-sale financial assets, which mainly include stock investment, bond investment and fund investment, companies hold these for the purpose of long-term investment. Generally speaking, financial companies prefer the first type of financial assets, because it is necessary for them to maintain adequate liquidity other than making longterm investments. Consequently, a financial asset at fair value through profit or loss has more significant value-relevance. The high coefficient of FAVI also provides evidence for the procyclical effects. Specifically, when it comes to economic slump, the fair value of financial assets decline. Investors are eager to sell-off their financial assets in order to stop loss. However, the huge quantities supplied could lead to further decrease in financial assets' fair value and vice versa.

For manufacturing firms, only the coefficient of FVAD is significant. This suggests that gain and loss arising from available-for-sale financial assets positively influences stock price, even though the effects are very limited. In terms of FVAl, it has no influence on share price. It is probably because unlike financial companies, tradable financial assets are not one of the main sources of profits for manufacturing firms. Normally, manufacturing companies would prefer stable longterm investments rather than short-term financial assets' trades with higher risks. Thus, in the manufacturing industry, only available-for-sale financial assets are value-relevant. 
Comparing the financial industry with the manufacturing industry, both financial assets measured by fair value are found value-relevant to share price. One possible reason could be the different financial assets holdings of the two industries. In general, financial companies possess a great number of financial assets. Thus, fair value changes tend to have more significant influences on their earnings, net assets and share price. Companies in the manufacturing industry are quite the opposite. From the $R^{2}$ of the models, it can be seen that the models based on the financial industry's data possess a better fitting degree. It implies that the accounting information of financial companies has stronger explanation power on share price compared with manufacturing companies. 


\section{Discussion and Conclusion}

In this paper, we investigate whether fair value information is value-relevant to listed companies in China. Majority of existing researches on value-relevance of fair value focus on financial institutions only. This study makes up for the research gap by dividing samples into financial companies and manufacturing companies and testing them respectively to investigate whether fair value information performs differently on value-relevance in the two industries. The results imply that fair value information in the financial industry has a strong explanation power to corporate share price. In contrast, the value-relevance of fair value information in manufacturing industry is limited. It is probably because financial companies hold much more financial assets than manufacturing companies. Therefore, the earnings, net assets and share price of financial corporations are considerably influenced by fair value changes. Also, for the financial industry, the fair values of financial assets at fair value through profit or loss are more value-relevant compared with fair values of available-for-sale financial assets. To conclude, the extent of value-relevance of fair value varies in different industries. For the financial industry, fair value information is significantly value-relevant. However, for the non-financial industry, for example the manufacturing industry, the value-relevance of fair value is limited.

The study is subject to several limitations. Firstly, fair value changes mainly come from two items: financial assets at fair value through profit or loss and available-for-sale financial assets. Nevertheless, other items may produce fair value changes, but are not included in our models, for example non-monetary assets exchange and debt restructuring. In current accounting standards, there are no clear requirements about the disclosure of these items, making it difficult to collect the information from corporate financial statements. The results could be biased with missing of fair value information of these minority items. Secondly, we choose total asset and asset-liability ration as control variables in our model. However, from the perspective of the macroscopic environment- macro-economy situation and stock market environment could also affect share price. Thirdly, we conduct the study under the assumption that of semistrong-form efficiency market. However, there is not enough evidence to prove China's stock market is semistrong-form efficient. These limitations should be corrected in future researches.

This study also encapsulates some realistic value in practice. First of all, it is not a wise choice to widen the range of fair value application blindly. The empirical results of the non-financial industry are not ideal. As such, fair value does not improve the relevance of accounting information for non-financial companies. At present, when the market is not mature enough, historical cost should still be the primary measurement method in our accounting system. It also requests accounting standard makers to find an appropriate extent of using fair value based on the specific situations in China, rather than imitating accounting standards of developed countries. Secondly, we need to establish a sound fair value application system. 
According to current accounting standards, financial assets can be divided into four types; moreover, every type of financial asset uses different measurement methods in initial measurement and subsequent measurement. However, the classification procedure is not objective, but rather quite subjective, which is based on the purpose of possession. Thus, managers could classify financial assets, as they need to manipulate profits. In order to ensure the reliability and relevance of fair value, detailed application guidance is urgently needed. Lastly, valuation techniques should be regulated. In 2010, the ministry of finance introduced three fair value hierarchies. For Level 3 , which does not have observable value on active markets, the measurement of Level 3 fair value relies heavily on valuation technique. Current accounting standards require that the valuation model chosen by firms should be recognized by all market participants. However, this requirement is not specific enough, so every company is likely to have different choices. As a result, the valuation outcomes are incomparable, and even biased from an asset's true value. Thus, it is necessary to issue a specific and unified standard for a valuation technique, to eliminate subjective factors during the valuation process. Another possible solution is to establish professional valuation institutions to improve the accuracy and comparability of valuation results.

\section{Acknowledgments}

None.

\section{References}

1. Ryan SG. Accounting in and for the Subprime Crisis. The Accounting Review. American Accounting Association; 2008;83: 1605-1638.

2. Plantin G, Sapra H, Shin HS. Fair Value Accounting and Financial Stability. 2008; doi:10.2139/ssrn.1275395

3. Richard J. The secret past of fair value: Lessons from history applied to the French case. Accounting in Europe. Taylor \& Francis; 2004;1: 95-107.

4. Bonaci CG, Tudor AT. Fair value empirical studies: an overview on acconting research literature. Annales Universitatis Apulensis: Series Oeconomica. " 1 Decembrie 1918” University of Alba lulia (Romania), Faculty of Sciences; 2011;13: 197.

5. White. The Disintegration of The Depositary Organizations: Bank and Depositary 
Organization Public Experience. Contemporary Accounting Research. 1991;10: 25-27.

6. Barth ME. Fair Value Accounting: Evidence from Investment Securities and the Market Valuation of Banks. The Accounting Review. American Accounting Association; 1994;69: 125.

7. Allen F, Carletti E. Mark-to-market accounting and liquidity pricing. J Account Econ. 2008;45: 358-378.

8. Ayres D, Huang X (sharon), Myring M. Fair value accounting and analyst forecast accuracy. Advances in Accounting. 2017;37: 58-70.

9. Lys T. Abandoning the transactions-based accounting model: Weighing the evidence. J Account Econ. 1996;22: 155-175.

10. Shleifer A. Inefficient Markets: An Introduction to Behavioral Finance. J Inst Theor Econ. 2002;158: 369-374.

11. Barberis N, Thaler R. A survey of behavioral finance. Handbook of the Economics of Finance. Elsevier; 2003;1: 1053-1128.

12. Ramanna K, Watts RL. Evidence on the Effects of Unverifiable Fair-Value Accounting. 2007; doi:10.2139/ssrn.1012139

13. Lin $\mathrm{Y}-\mathrm{H}$, Lin $\mathrm{S}$, Fornaro JM, Huang $\mathrm{H}-\mathrm{WS}$. Fair value measurement and accounting restatements. Advances in Accounting. 2017;38: 30-45.

14. Plantin G, Sapra H, Shin HS. Fair Value Accounting and Financial Stability. 2008; doi:10.2139/ssrn.1275395

15. Adrian T, Shin HS. The Changing Nature of Financial Intermediation and the Financial Crisis of 2007-2009. Annual Reviews; 2010; doi:10.1146/annurev.economics.102308.124420

16. Magnan $M$, Menini A, Parbonetti A. Fair value accounting: information or confusion for financial markets? Rev Account Stud. Springer US; 2015;20: 559-591.

17. Chalmers KG, Godfrey JM. Practice versus Prescription in the Disclosure and Recognition of Derivatives. Australian Accounting Review. Blackwell Publishing Ltd; 2000;10: 40-50.

18. Peng S, Bewley K. Adaptability to fair value accounting in an emerging economy: A case study of China's IFRS convergence. Accounting, Auditing \& Accountability Journal. 2010;23: 982-1011. 
19. Barth ME, Beaver WH, Landsman WR. Value-Relevance of Banks' Fair Value Disclosures under SFAS No. 107. The Accounting Review. American Accounting Association; 1996;71: 513-537.

20. Venkatachalam M. Value-relevance of banks' derivatives disclosures. J Account Econ. 1996;22: 327-355.

21. Mengle D. The Feasibility of Market Value Accounting for Commercial Banks. 1989; Available: https://papers.ssrn.com/sol3/papers.cfm?abstract_id=2123523

22. Nelson KK. Fair Value Accounting for Commercial Banks: An Empirical Analysis of SFAS No. 107. The Accounting Review. American Accounting Association; 1996;71: 161-182.

23. Eccher EA, Ramesh K, Thiagarajan SR. Fair value disclosures by bank holding companies. J Account Econ. 1996;22: 79-117.

24. Petroni KR, Wahlen JM. Fair Values of Equity and Debt Securities and Share Prices of Property-Liability Insurers. J Risk Insur. [American Risk and Insurance Association, Wiley]; 1995;62: 719-737.

25. Khurana IK, Kim M-S. Relative value relevance of historical cost vs. fair value: Evidence from bank holding companies. J Account Public Policy. 2003;22: 19-42.

26. Kolev KS. Do Investors Perceive Marking-to-Model as Marking-to-Myth? Early Evidence from FAS 157 Disclosure. 2008; doi:10.2139/ssrn.1336368

27. Goh BW, Li D, Ng J, Ow Yong K. Market pricing of banks' fair value assets reported under SFAS 157 since the 2008 financial crisis. J Account Public Policy. 2015;34: 129-145.

28. Ahmed AS, Takeda C. Stock market valuation of gains and losses on commercial banks' investment securities An empirical analysis. J Account Econ. 1995;20: 207-225.

29. Hodder LD, Hopkins PE, Wahlen JM. Risk-relevance of fair-value income measures for commercial banks. The Accounting Review. 2006;81: 337-375.

30. Arouri MEH, Bellalah M, Hamida NB, Nguyen DK. Relevance of fair value accounting for financial instruments: some French evidence. International journal of business. Premier Publishing, Inc.; 2012;17: 209.

31. Bernard VL, Merton RC, Palepu KG. Mark-to-Market Accounting for Banks and Thrifts: Lessons from the Danish Experience. Journal of Accounting Research. [Accounting Research Center, Booth School of Business, University of Chicago, Wiley]; 1995;33: 1-32. 
32. Richard Dietrich J, Harris MS, Muller KA. The reliability of investment property fair value estimates. J Account Econ. 2000;30: 125-158.

33. Hung $M$, Subramanyam KR. Financial statement effects of adopting international accounting standards: the case of Germany. Rev Acct Stud. Springer US; 2007;12: 623-657.

34. Fama EF. Efficient Capital Markets: I1. Available:

http://faculty.chicagobooth.edu/jeffrey.russell/teaching/Finecon/readings/fama.pdf

35. Beaver WH, Dukes RE. Interperiod Tax Allocation, Earnings Expectations, and the Behavior of Security Prices. The Accounting Review. American Accounting Association; 1972;47: 320-332.

36. Feltham GA, Ohlson JA. Valuation and Clean Surplus Accounting for Operating and Financial Activities*. Contemporary Accounting Research. Blackwell Publishing Ltd; 1995;11: 689-731.

37. Collins DW, Maydew EL, Weiss IS. Changes in the value-relevance of earnings and book values over the past forty years. J Account Econ. 1997;24: 39-67. 